\title{
PENGARUH BIAYA BAURAN PROMOSI TERHADAP VOLUME PENJUALAN PADA PT. BINTANG BALI INDAH SINGARAJA TAHUN 2016
}

\author{
Komang Rian Tiniasti ${ }^{1}$, Kadek Rai Suwena ${ }^{2}$, I Nyoman Sujana ${ }^{3}$ \\ Jurusan Pendidikan Ekonomi \\ Universitas Pendidikan Ganesha \\ Singaraja, Indonesia \\ e-mail: riantiniasti@yahoo.com ${ }^{1,}$ kadek_suwena@yahoo.co.id ${ }^{2}$, \\ sujanatbn@yahoo.com ${ }^{3}$
}

\begin{abstract}
Abstrak
Penelitian ini bertujuan untuk mengetahui pengaruh biaya display, biaya diskon dan biaya penjualan perorangan terhadap volume penjualan pada PT. Bintang Bali Indah Singaraja Tahun 2016, baik secara parsial maupun simultan. Jenis penelitian ini merupakan penelitian kausalitas. Subjek penelitian adalah bagian pemasaran, sedangkan objek penelitian adalah data biaya display, biaya diskon, biaya penjualan perorangan dan volume penjualan PT. Bintang Bali Indah Singaraja Tahun 2016. Metode yang digunakan untuk mengumpulkan data adalah dokumentasi dan dianalisis dengan regresi linier berganda melalui Statistical Program Social Science (SPSS) 16.0 for windows. Hasil penelitian menunjukkan bahwa biaya display tidak berpengaruh signifikan terhadap volume penjualan ditunjukkan dari nilai $t_{\text {hitung }}<t_{\text {tabel }}(-0.742<1,833)$, biaya diskon berpengaruh signifikan terhadap volume penjualan ditunjukkan dari nilai $t_{\text {hitung }}>$ $t_{\text {tabel }}(2.422>1,833)$, biaya penjualan perorangan tidak berpengaruh signifikan terhadap volume penjualan ditunjukkan dari nilai $t_{\text {hitung }}<t_{\text {tabel }}(1.718<1.833)$ dan biaya display, biaya diskon dan biaya penjualan perorangan berpengaruh terhadap volume penjualan pada PT. Bintang Bali Indah Singaraja Tahun 2016 ditunjukkan dari nilai $F_{\text {hitung }}>F_{\text {tabel }}$ (5.038 > 1.833).
\end{abstract}

Kata kunci : biaya promosi, bauran promosi, volume penjualan.

\begin{abstract}
This study aims to determine the effect of display costs, discount costs and individual sales costs on sales volume at PT. Bintang Bali Indah Singaraja Year 2016, either partially or simultaneously. This type of research is a causality study. Research subject is part of marketing, while the object of research is display cost data, discount cost, individual sales cost and sales volume of PT. Bintang Bali Indah Singaraja Year 2016. The method used to collect data is documentation and analyzed by multiple linear regression through Statistical Program Social Science (SPSS) 16.0 for windows. The result of the research shows that the cost of display does not have significant effect to sales volume. It is shown from ttest $<$ ttabel $(-0.742<1,833)$, discount cost has significant effect to sales volume, it is shown from ttest $>$ ttable $(2.422>1.833)$, individual sales cost has no significant effect of sales volume is shown from ttest <ttable $(1.718<1.833)$ and display cost, discount cost and individual selling cost influence to sales volume at PT. Bintang Bali Indah Singaraja Year 2016 is shown from Fcount> Ftable (5.038> 1.833).
\end{abstract}

\section{PENDAHULUAN}

Keywords: promotion cost, promotion mix, sales volume.

Munculnya perusahaan-perusahaan

baru dalam skala besar, sedang, maupun kecil, menambah semarak persaingan di dalam dunia bisnis sejalan dengan pertumbuhan kondisi perekonomian, sosial, budaya dan teknologi. Langkah-langkah untuk dapat meningkatkan daya saing menjadi sangat vital untuk dapat 
memanfaatkan peluang yang ada seoptimal mungkin. Berbagai strategi penjualan bisa dilakukan untuk tetap mempertahankan kelangsungan perusahaan. Strategi penjualan merupakan alat fundamental yang direncanakan untuk mencapai tujuan perusahaan dengan mengembangkan keunggulan bersaing yang berkesinambungan melalui pasar yang dimasuki dan program penjualan yang digunakan untuk melayani pasar sasaran tertentu. Strategi penjualan memainkan peranan penting dalam membantu kesuksesan suatu perusahaan dalam berbagai kegiatan industry dan juga merupakan suatu proses penting untuk memperoleh keuntungan dan keunggulan bersaing, yang menuntut persiapan aktif dan seluruh fungsi bisnis utama dalam organisasi. Strategi penjualan dipedomani oleh keputusan manajemen tingkat atas tentang bagaimana, kapan dan dimana akan bersaing. Hal ini karena perusahaan sebagai suatu unit kerja selalu berusaha untuk mengorganisir segala sumber daya yang ada agar dalam aktifitasnya dapat tercapai hasil yang maksimal, yang akhirnya diharpakan dapat meningkatkan volume penjualan.

Volume menurut kamus Bahasa Indonesia adalah besarnya, banyaknya, bobot. Dalam hal ini dapat diartikan secara unit atau totalnya. Sedangkan penjualan merupakan interaksi antar individu, saling bertemu muka yang ditunjukkan untuk menciptakan, memperbaiki, menguasai, atau mempertahankan hubungan pertukaran yang saling menguntungkan dengan pihak lain. (Dharmmesta \& Irawan, 2010). Penjualan adalah salah satu kegiatan yang dilakukan oleh perusahaan dengan syarat memasarkan hasil produksinya baik berupa barang maupun jasa. Penjualan merupakan ilmu dan seni mempengaruhi pribadi yang dilakukan oleh penjual untuk mengajak orang lain bersedia membeli barang atau jasa yang ditawarkan. Perusahaan tidak dapat berkembang apabila dalam penjualan produk yang dihasilkan tidak dapat berkompetisi dengan pesaing. Jika suatu perusahaan mampu terus meningkatkan penjualan, maka perusahaan tersebut akan dapat bersaing dengan para pesaingnya. Tujuan umum penjualan dalam perusahaan yaitu mencapai volume penjualan, mendapatkan laba tertentu dan menunjang pertumbuhan perusahaan. (Swastha, 2004:404).

Menurut Daryono (2011), volume penjualan merupakan ukuran yang menunjukan banyak atau besarnya jumlah barang atau jasa yang terjual. Sedangkan menurut Swastha (2002), volume penjualan adalah penjualan bersih dari laporan laba perusahaan, penjualan bersih diperoleh melalui hasil penjualan seluruh produk (produk lini) selama jangka waktu tertentu, dan hasil penjualan yang dicapai dari market share (pangsa pasar) yang merupakan penjualan potensial, yang bisa terdiri dari kelompok teritorial dan kelompok pembeli selama jangka waktu tertentu. Volume penjualan merupakan salah satu bentuk baku dari kinerja perusahaan. Berhasil tidaknya suatu perusahaan dapat dilihat dari kondisi volume penjualan secara keseluruhan. Volume penjualan disini juga sebagai salah satu bentuk kinerja perusahaan dalam menjalankan kegiatan usahanya, tujuan utama dari perusahaan adalah untuk memperoleh keuntungan. Salah satunya ialah dengan meningkatkan volume penjualan yang dihasilkan oleh perusahaan. Peningkatan volume penjualan bagi perusahaan merupakan salah satu tujuan utama disamping mendapatkan laba yang maksimum serta menunjang perkembangan perusahaan. Volume penjualan disini juga sebagai salah satu bentuk kinerja perusahaan dalam menjalankan kegiatan usahanya.

Kotler (2000:55) menyatakan ada beberapa faktor yang mempengaruhi volume penjualan antara lain harga jual, produk, biaya promosi, saluran distribusi dan mutu. Volume penjualan juga dipengaruhi oleh dua faktor lingkungan, yaitu: faktor lingkungan tak terkendali terdiri dari lingkungan persaingan, ekonomi, teknologi, politik, hukum, dan sosial budaya dan faktor lingkungan terkendali adalah faktor lingkungan yang mempengaruhi pemasaran termasuk penjualan yang berada di dalam perusahaan. Volume penjualan merupakan faktor yang mempengaruhi besarnya laba perusahaan dan juga merupakan fungi dari harga barang, promosi serta harga pesaing. 
Sebagai upaya untuk meningkatkan volume penjualan dapat dilakukan dengan cara sistem pemasaran yang tepat. Pemasaran adalah suatu perpaduan dari aktivitas-aktivitas yang saling berhubungan untuk mengetahui kebutuhan konsumen melalui penciptaan, penawaran dan pertukaran produk dan jasa yang bernilai serta mengembangkan promosi, distribusi, pelayanan, dan harga agar kebutuhan konsumen dapat terpuaskan. (Oentoro, 2012). Menurut Handayani (2012), pemasaran mengidentifikasikan kebutuhan dan keinginan konsumen pasar sasarannya. Serta bagaimana memuaskan mereka melalui proses pertukaran dengan tetap memperhatikan semua pihak dan tujuannya terkait dengan kepentingan perusahaan. Pemasaran merupakan salah satu kegiatan pokok yang dilakukan perusahaan untuk mempertankan kelangsungan hidupnya, berkembang dan menghasilkan laba. Pemasaran menjadi salah satu cara perusahaan untuk memasarkan produk atau jasa yang dihasilkan kepada konsumen sebagai pemakai. Kegiatan pemasaran bukan hanya sekedar menyampaikan barang dari produsen ke konsumen, tetapi lebih dari itu, bagaimana membuat konsumen tertarik membeli produk kita dan memuaskannya. Hal ini membutuhkan komunikasi pemasaran yang baik untuk mempertahankan tingkat permintaan guna menghadapi berubahnya pilihan konsumen dan meningkatnya persaingan. Komunikasi pemasaran (marketing communication) adalah suatu sarana dimana para pelaku usaha berusaha untuk memberikan informasi, membujuk dan mengingatkan kembali konsumen secara langsung atau tidak langsung tentang produk atau jasa yang ditawarkannya. Komunikasi pemasaran mempresentasikan "suara" para pelaku usaha atas produk atau jasanya serta merupakan suatu sarana dimana para pelaku usaha dimana para pelaku usaha dapat membuat sebuah dialog dan membangun hubungan yang baik dengan konsumen. Komunikasi pemasaran dalam sebuah perusahaan merupakan aktivitas untuk menyebarkan informasi, memengaruhi, membujuk, dan mengingatkan sasaran pasar agar konsumen bersedia menerima, membeli dan loyal pada produk yang ditawarkan oleh perusahaan. (Tjiptono, 2008:219).

Salah satu bentuk komunikasi pemasaran dalam bisnis itu adalah promosi. Promosi menjadi sarana untuk mengenalkan produk kepada para konsumen, membuat konsumen sadar akan produk-produk baru, mendidik mereka tentang berbagai fitur dan manfaat merek, serta memfasilitasi penciptaan citra sebuah perusahaan yang menghasilkan produk atau jasa. Promosi merupakan sejenis komunikasi yang memberi penjelasan yang meyakinkan calon konsumen tentang barang dan jasa (Alma, 2013:179). Promosi (komunikasi pemasaran) adalah aktivitas pemasaran yang berusaha menyebarkan informasi, mempengaruhi/membujuk, dan/atau mengingatkan pasar sasaran atas perusahaan dan produknya agar bisa bersedia menerima, membeli, loyal pada produk yang ditawarkan perusahaan yang bersangkutan. (Tjiptono, 2008). Promosi bertujuan untuk menginformasikan suatu produk dan menarik perhatian calon pelanggan sehingga membeli produk tersebut. Promosi dapat menjadi salah satu senjata ampuh dalam menghadapi tingkat persaingan, sehingga tujuan perusahaan memperoleh keuntungan yang sebesarbesarnya dapat dicapai melalui peningkatan volume penjualan. Perusahaan dapat menggunakan bauran promosi yang merupakan paduan spesifikasi seperti periklanan, promosi penjualan, hubungan masyarakat, penjualan personal dan pemasaran langsung yang digunakan perusahaan untuk memberikan informasi kepada konsumen, mengkomunikasikan nilai pelanggan secara persuasif dan membangun hubungan pelanggan . (Kotler \& Amstrong, 2008:116).

Menurut Lupiyoadi (2013), bauran promosi adalah perangkat yang mencakup aktivitas periklanan (advertising), penjualan perseorangan (personal selling), promosi penjualan (sales promotion), hubungan masyarakat (humas atau public relation), pemasaran langsung (direct marketing), dan pemasaran (marketing publication). Bauran promosi pada hakikatnya adalah suatu bentuk komunikasi pemasaran yang merupakan aktiftas pemasaran yang 
berusaha menyebarkan informasi, mempengaruhi dan meningkatkan pasar sasaran atas perusahaan dan produknya agar bersedia menerima, membeli, dan loyal pada produk yang ditawarkan perusahaan yang bersangkutan. (Alma, 2005:179). Sedangkan menurut Kotler \& Amstrong (2012:363) bauran promosi dijelaskan sebagai berikut:

"Perpaduan spesifikasi iklan, promosi penjualan, hubungan masyarakat, penjual personal, dan sarana pemasaran langsung yang digunakan perusahaan untuk mengkomunikasikan nilai pelanggan secara persuasive dan membangun hubungan pelanggan, gabungan dari alat-alat promosi yang dirancang untuk mencapai tujuan serta memberikan informasi yang mengarahkan konsumen untuk terbujuk melakukan pembelian". Untuk itu, diperlukan adanya suatu strategi pemasaran dengan cara menerapkan bauran promosi (promotion mix) yang tepat, agar tujuan perusahaan tercapai. Konsep bauran promosi ini secara umum sering digunakan sebagai alat untuk menyampaikan pesan kepada konsumen. Dengan promosi dapat membantu perusahaan meningkatkan penjualan sesuai dengan target yang telah ditetapkan. Untuk itu, diperlukan adanya suatu strategi pemasaran dengan cara menerapkan bauran promosi (promotion mix) yang tepat, agar tujuan perusahaan tercapai. Konsep bauran promosi ini secara umum sering digunakan sebagai alat untuk menyampaikan pesan kepada konsumen.

Mengingat pentingnya bauran promosi bagi perusahaan di dalam pemasaran suatu produk yang berkaitan dengan volume penjualan maka perlu diperhatikan serius, apabila pemilik perusahaan mengharapkan perusahaannya mendapatkan tempat yang luas di pasaran, mampu bersaing dengan perusahan perusahan lain dan dapat bertahan dalam jangka waktu yang panjang serta mengalami perkembangan yang pesat maka pemilik perusahaan harus dapat melaksanakan strategi dan pemasaran yang tepat dan benar. Apabila aktivitas promosi yang dilakukan oleh perusahaan mengalami penurunan maka hal ini mengakibatkan pada penurunan volume penjualan karena promosi juga merupakan salah satu cara meningkatkan penjualan. Kismono (2001:374). Kegiatan promosi sendiri tidak terlepas dari biaya, karena berhasil tidaknya memasarkan suatu produk tergantung keahlian marketing dan promosi, sedangkan biaya promosi itu sangat mempengaruhi hasil penjualan. Menurut Simamora (2010) biaya promosi merupakan sejumlah dana yang dikeluarkan perusahaan ke dalam promosi untuk meningkatkan penjualan. Besarnya biaya promosi akan mempengaruhi volume penjualan perusahaan. Biaya promosi merupakan pengorbanan perusahaan dalam rangka mengkomunikasikan informasi dari penjual kepada pembeli.

PT. Bintang Bali Indah Singaraja merupakan perusahaan distributor, dimana di dalam operasional kerjanya dibagi menjadi 4 divisi, yaitu Produk Bintang , Bandulan, Bendera dan ABC. Perkembangan perusahaan pada saat ini cukup baik, akan tetapi untuk sebagian produk yaitu pada produk Bendera mengalami penurunan penjualan. Adanya pesaing-pesaing baru dengan merek lain yang spesifikasi dan harganya hampir sama sehingga menimbulkan suatu kompetisi antar competitor yang semakin ketat dalam penjualan dan pengoperasian perusahaan, dan juga disebabkan oleh kurangnya informasi mengenai kelebihan dan kekurangan competitor yang dimungkinkan akan dapat mempengaruhi penurunan penjualan. Untuk menghadapi persaingan tersebut maka perusahaan harus berusaha semaksimal mungkin bagaimana agar perusahaan dapat meningkatkan volume penjualan untuk seluruh produk yang dihasilkan dan disertai peningkatan keuntungan dengan melakukan upaya mencapaian tujuan penjualan melalui kegiatan promosi. Kegiatan promosi yang dilakukan perusahaan memerlukan dana tersendiri dan diharapkan dengan dana tersebut, pemasaran secara keseluruhan dapat diarahkan dan dikendalikan dengan baik dan dapat berperan secara berarti dalam mengembangkan laju penjualan.

Berdasarkan observasi awal yang peneliti lakukan melalui wawancara dengan bagian pemasaran menunjukkan terjadi penurunan volume penjulan dari bulan 
September sampai bulan Desember 2016 pada produk Bendera. Rincian penjualannya, yaitu : (a) bulan September Rp.1.682.121.660; (b) bulan Oktober Rp. 1.584.793.731; (c) bulan November Rp. 1.398.641.897 dan bulan Desember Rp. 1.188.849.757. Target penjualan bulan September adalah 1,9 $\mathrm{M}$ dan yang mampu tercapai 1,6 M, ini menunjukkan target penjualan belum tercapai yang ditunjukkan dengan selisih penjualan sebesar Rp. 317.215.346. Bulan Oktober target penjualanya 1,6 M tercapai 1,5 M dengan selisih penjualan sebesar Rp. 97.327.929. Bulan November target penjualannya 1,5 M tercapai 1,3 $\mathrm{M}$ dengan selisih penjualan sebesar Rp. 186.151.834 dan di bulan Desember target penjualan yang ingin dicapai adalah $1,5 \mathrm{M}$ tetapi yang tercapai hanya 1,1 $\mathrm{M}$ dengan selisih penjualan sebesar Rp. 209.792.140. Penurunan volume penjualan secara signifikan tersebut tidak sesuai dengan target penjualan produk perusahaan. Hal ini tentu sangat bepengaruh terhadap kinerja perusahaan. Oleh karena itu, perlu adanya penelitian untuk mengidentifikasi pengaruh biaya bauran promosi terhadap volume penjualan mengingat pentingnya penjualan bagi perusahaan. Penelitian ini mencoba untuk mengetahui apakah biaya bauran promosi yaitu periklanan melalui media display, promosi penjualan melalui pemberian diskon dan biaya penjualan perorangan yang sudah dilaksanakan PT. Bintang Bali Indah Singaraja khususnya pada produk Bendera Tahun 2016 secara signifikan mempengaruhi volume penjualan.

\section{METODE PENELITIAN}

Jenis penelitian ini merupakan penelitian kausalitas. Penelitian kausalitas merupakan tipe penelitian dengan karakteristik masalah berupa hubungan sebab-akibat antara dua variabel atau lebih. Adapun tujuan penelitian ini adalah untuk mengetahui pengaruh biaya bauran promosi terhadap volume penjualan pada PT. Bintang Bali Indah Singaraja Tahun 2016. Penelitian ini menggunakan dua variabel yaitu variabel bebas dan variabel terikat. Adapun yang menjadi variabel bebas dalam penelitian ini adalah biaya display $\left(\mathrm{X}_{1}\right)$, biaya diskon $\left(\mathrm{X}_{2}\right)$, biaya penjualan perorangan $\left(X_{3}\right)$ dan varibel terikatnya adalah volume penjualan $(\mathrm{Y})$.

Subjek penelitian adalah orang, tempat, atau benda yang diamati dalam rangka sebagai sasaran (Kamus Bahasa Indonesia, 1989). Dalam Penelitian ini yang menjadi subjek penelitian adalah karyawan bagian pemasaran di PT. Bintang Bali Indah Singaraja. Sedangkan menurut Dajan (2000) objek penelitian adalah pokok persoalan yang hendak diteliti untuk mendapatkan data lebih terarah. Objek dalam penelitian ini adalah data biaya display, biaya diskon, biaya penjualan personal perorangan dan volume penjualan PT. Bintang Bali Indah Singaraja Tahun 2016.

Jenis data yang digunakan dalam penelitian ini adalah data kuantitatif. Jenis data kuantitatif yaitu dalam bentuk angkaangka yang menunjukan nilai dari besaran atau variabel yang mewakilinya, data tersebut yakni biaya display, diskon, biaya penjualan perorangan dan volume penjualan, yang diperoleh dari laporan perusahaan PT. Bintang Bali Indah Singaraja Tahun 2016. Dalam penelitian ini menggunakan data sekunder adalah data yang diperoleh dari arsip atau dokumendokumen yakni biaya display, diskon, penjualan perorangan yang dikeluarkan perusahaan dan volume penjualan yang terdapat pada PT. Bintang Bali Indah Singaraja. Metode pengumpulan data dalam penelitian ini adalah menggunakan metode dokumentasi, teknik dokumentasi yaitu pengumpulan data dengan cara-cara mencatat hal-hal yang berhubungan dengan masalah penelitian. Penelitian ini menggunakan metode analisis regresi linier berganda untuk mengetahui pengaruh variabel bebas $(X)$ terhadap variabel terikat (Y) melalui program statistical package for social sciences (SPSS) for windows versi 16.

\section{HASIL DAN PEMBAHASAN Hasil}

Hasil analisis $u j i$ t dengan menggunakan program SPSS 16,0 for windows menunjukkan besarnya pengaruh biaya display terhadap volume penjualan dapat dilihat pada tabel 1 . 
Tabel 1. Hasil Uji T Untuk Variabel Biaya Display

\begin{tabular}{cc} 
Unstandardized & Standardized \\
\hline Coefficients & Coefficients
\end{tabular}

\begin{tabular}{|c|c|c|c|c|c|c|}
\hline Model & & $B$ & Std. Error & Beta & $t$ & Sig. \\
\hline 1 & $\begin{array}{l}\text { (Constant) } \\
\text { Blaya Uisplay }\end{array}$ & $\begin{array}{l}\text { 7.588E8 } \\
-17.431\end{array}$ & $\begin{array}{l}\text { 8.492E8 } \\
23.506\end{array}$ & -.343 & $\begin{array}{l}.894 \\
-.742\end{array}$ & $\begin{array}{l}.398 \\
.480\end{array}$ \\
\hline
\end{tabular}

Berdasarkan tabel 1 menunjukkan bahwa variabel biaya display tidak memiliki pengaruh yang signifikan terhadap volume penjualan. Hal ini dapat dilihat dari nilai $t_{\text {hitung }}=-0.742<t_{\text {tabel }}=1,833$ atau $p$-value $=$ $0.480>\alpha=0.05$, maka $\mathrm{HO}$ diterima dan $\mathrm{Ha}$ ditolak. Jadi, dapat disimpulkan bahwa variabel biaya display tidak memiliki pengaruh yang signifikan terhadap volume penjualan pada PT. Bintang Bali Indah Singaraja Tahun 2016.

Pengaruh biaya diskon terhadap volume penjualan pada PT. Bintang Bali Indah Singaraja dapat dilihat pada tabel 2 .

Tabel 2. Hasil Uji T Untuk Variabel Biaya Diskon

\begin{tabular}{|c|c|c|c|c|c|c|}
\hline \multirow{2}{*}{\multicolumn{2}{|c|}{ Model }} & \multicolumn{2}{|c|}{$\begin{array}{l}\text { Unstandardized } \\
\text { Coefficients }\end{array}$} & \multirow{2}{*}{$\begin{array}{l}\text { Standardized } \\
\text { Coefficients } \\
\text { Beta }\end{array}$} & \multirow[b]{2}{*}{$\mathrm{t}$} & \multirow[b]{2}{*}{ Sig. } \\
\hline & & $B$ & Std. Error & & & \\
\hline 1 & $\begin{array}{l}\text { (Constant) } \\
\text { Biaya Diskon }\end{array}$ & $\begin{array}{r}7.588 \mathrm{E} 8 \\
8.244\end{array}$ & $\begin{array}{l}8.492 \mathrm{E} 8 \\
3.404\end{array}$ & .840 & $\begin{array}{l}.894 \\
2.422\end{array}$ & $\begin{array}{l}.398 \\
.042\end{array}$ \\
\hline
\end{tabular}

Berdasarkan tabel 2 menunjukkan bahwa variabel biaya diskon memiliki pengaruh yang signifikan terhadap volume penjualan. Hal ini dapat dilihat dari nilai $t_{\text {hitung }}=2.422>t_{\text {tabel }}=1,833$ atau $p$-value $=$ $0.042<\alpha=0.05$, maka $\mathrm{HO}$ ditolak dan $\mathrm{Ha}$ diterima. Jadi, dapat disimpulkan bahwa variabel biaya diskon memiliki pengaruh yang signifikan terhadap volume penjualan pada PT. Bintang Bali Indah Singaraja Tahun 2016.

Pengaruh biaya penjualan perorangan terhadap volume penjualan pada PT. Bintang Bali Indah Singaraja dapat dilihat pada tabel

Tabel 3. Hasil Uji T Untuk Variabel Biaya Penjualan Perorangan

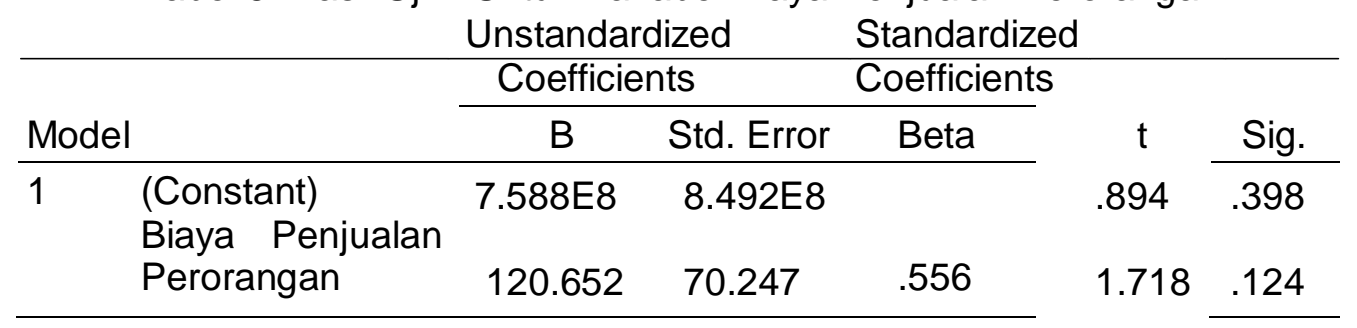

Berdasarkan tabel 3 menunjukkan bahwa variabel biaya penjualan perorangan tidak memiliki pengaruh yang signifikan terhdap volume penjualan. Hal ini dapat dilihat dari nilai $t_{\text {hitung }}=1.718<\mathrm{t}_{\text {tabel }}=1.833$ atau $p$-value $=0.124>\alpha=0.05$, maka $\mathrm{HO}$

diterima dan $\mathrm{Ha}$ ditolak. Oleh karena itu, dapat disimpulkan bahwa variabel penjualan perorangan tidak memiliki pengaruh yang signifikan terhadap volume penjualan pada PT. Bintang Bali Indah Singaraja Tahun 2016. Pengaruh biaya 
display, biaya diskon dan biaya penjualan perorangan terhadap volume penjualan pada PT. Bintang Bali Indah Singaraja dapat dilihat pada tabel 4 .

Tabel 4. Hasil Perhitungan Uji F

\begin{tabular}{lllllll}
\hline Model & & Sum Squares & Df & Mean Squares & $F$ & Sig. \\
\hline 1 & Regression & $2.781 \mathrm{E} 17$ & 3 & $9.271 \mathrm{E} 16$ & 5.038 & $.030^{\mathrm{a}}$ \\
& Residual & $1.472 \mathrm{E} 17$ & 8 & $1.840 \mathrm{E} 16$ & & \\
& total & $4.254 \mathrm{E} 17$ & 1 & & & \\
\hline
\end{tabular}

Berdasarkan tabel 4 menunjukkan bahwa $F_{\text {hitung }}=5.038>F_{\text {tabel }}=1.833$ atau $p$ value $=0.030<\alpha=0,05$, maka Ha diterima. Jadi, dapat disimpulkan bahwa variabel biaya display $\left(X_{1}\right)$, biaya diskon $\left(X_{2}\right)$ dan biaya penjualan perorangan $\left(X_{3}\right)$ secara simultan memiliki pengaruh yang signifikan terhadap variabel volume penjualan $(\mathrm{Y})$.
Untuk mengetahui besarnya pengaruh biaya display, biaya diskon dan biaya penjualan perorangan terhadap volume penjualan, maka dapat digunakan analisis koefisien determinasi (Adjusted $R$ Square). Besarnya koefisien determinasi (Adjusted $R$ Square) dapat dilihat pada tabel

Tabel 5. Hasil Perhitungan Koefisien Determinasi

\begin{tabular}{|c|c|c|c|c|}
\hline \multicolumn{5}{|c|}{ Model Summary } \\
\hline & & & Adjusted R & Std. Error of \\
\hline Model & $\mathrm{R}$ & R Square & Square & the Estimate \\
\hline 1 & $.809^{a}$ & .654 & .524 & 1.357E8 \\
\hline
\end{tabular}

Berdasarkan tabel 5 dengan biaya diskon dan biaya penjualan menggunakan program SPSS 16.0 for perorangan, sedangkan sisanya sebesar windows menunjukkan bahwa besarnya 47,6\% dipengaruhi oleh faktor lain yang pengaruh biaya display, biaya diskon dan tidak termasuk dalam penelitian ini.

biaya penjualan perorangan terhadap Berdasarkan pengolahan data yang variabel volume penjualan secara simultan digunakan untuk mengetahui persamaan sebesar 0,524 sehingga besarnya garis regresi, pengaruh biaya display, biaya pengaruh variabel biaya display $\left(\mathrm{X}_{1}\right)$, biaya diskon dan biaya penjualan perorangan diskon $\left(X_{2}\right)$ dan biaya penjualan perorangan terhadap volume penjualan pada PT. $\left(X_{3}\right)$ terhadap volume penjualan $(Y)$ adalah Bintang Bali Indah Singaraja Tahun 2016 sebesar 52,4\%. Hal ini berarti volume digunakan analisis koefisien beta. Besarnya penjualan pada PT. Bintang Bali Indah 6.6 koefisien beta yaitu dapat dilihat pada tabel Singaraja Tahun 2016 sebesar 52,4\% ditentukan oleh variabel biaya display,

Tabel 6. Hasil perhitungan Koefisien Beta (Uji Persamaan Regresi) Unstandardized Standardized

\begin{tabular}{|c|c|c|c|c|c|c|}
\hline & & Unstandardized & & Standardized & & \\
\hline & & Coefficients & & Coefficients & & \\
\hline Model & & $B$ & Std. Error & Beta & $\mathrm{t}$ & Siq \\
\hline 1 & (Constant) & $7.588 E 8$ & 8.492E8 & & .894. & .398 \\
\hline & Biaya Display & -17.431 & 23.506 & -.343 & -.742 & .480 \\
\hline & $\begin{array}{l}\text { Biaya Diskon } \\
\text { Biaya Penjualan }\end{array}$ & 8.244 & 3.404 & .840 & 2.422 & .042 \\
\hline & Perorangan & 120.652 & 70.247 & .556 & 1.718 & .124 \\
\hline
\end{tabular}


Berdasarkan tabel 6 dengan mengunakan program SPSS 16.0 for windows dapat dibuat persamaan garis regresi. Persamaan garis regresi yang dapat dibuat untuk menggambarkan pengaruh biaya display, biaya diskon dan biaya penjualan perorangan terhadap volume penjualan adalah sebagai berik tt. $\hat{Y}=7.588 \mathrm{E} 8-17,431 \mathrm{X}_{1}+8,244 \mathrm{X}_{2}+$ $120,652 X_{3}$

Keterangan:

$\ddot{Y}=$ volume penjualan,

$\mathrm{X}_{1}=$ biaya display,

$\mathrm{X}_{2}=$ biaya diskon,

$\mathrm{X}_{3}=$ biaya penjualan perorangan

Interpretasi dari yaitu: Konstanta 7.588E8 menunjukan bahwa jika variabel bebas biaya display $\left(X_{1}\right)$, biaya diskon $\left(X_{2}\right)$ dan biaya penjualan perorangan $\left(X_{3}\right)$ sama dengan nol, maka promosi penjualan (Y) akan mengalami kenaikan sebesar 7.588E8 satuan. Koefisien regresi $-17,431$ berarti jika variabel biaya display $\left(X_{1}\right)$ meningkat tiap satu satuan, maka volume penjualan (Y) akan mengalami penurunan sebesar 17,431 dengan syarat variabel bebas lainnya tetap. Koefisien regresi 8,244 berarti jika variabel biaya diskon $\left(X_{2}\right)$ meningkat tiap satu satuan, maka volume penjualan (Y) akan mengalami peningkatan sebesar 8,244 dengan syarat variabel bebas lainnya tetap. Koefisien regresi 120,652 berarti jika variabel biaya penjualan perorangan $\left(X_{3}\right)$ meningkat tiap satu satuan, maka volume penjualan (Y) akan mengalami peningkatan sebesar 120,652 dengan syarat variabel bebas lainnya tetap.

\section{PEMBAHASAN}

Berdasarkan hasil penelitian yang dilakukan mengenai pengaruh biaya bauran promosi terhadap volume penjualan pada PT. Bintang Bali Indah Singaraja Tahun 2016 khususnya pada produk Bendera, maka diketahui bahwa biaya bauran promosi yaitu periklanan melalui media display dan penjualan perorangan secara parsial tidak memiliki pengaruh yang signifikan terhadap volume penjualan. Hal ini tidak sejalan dengan teori Simamora (2010) yang mengatakan bahwa biaya promosi merupakan sejumlah dana yang dikeluarkan perusahaan ke dalam promosi untuk meningkatkan volume penjualan.
Besarnya biaya promosi akan mempengaruhi tingkat penjualan perusahaan. Perbedaan ini terjadi karena objek dalam penelitian ini serta kondisi perusahaan berbeda dimana anggaran untuk biaya promosi yaitu melalui display dan penjualan perorangan masih kurang memadai sehingga biaya promosi perlu ditingkatkan untuk memudahkan perusahaan memilih media promosi yang lainnya.

Hasil temuan ini menunjukkan bahwa biaya promosi penjualan melalui pemberian diskon memiliki pengaruh yang signifikan terhadap volume penjualan pada PT. Bintang Bali Indah Singaraja Tahun 2016. Promosi penjualan merupakan bagian dari kegiatan promosi yang bersifat jangka pendek. Promosi penjualan yang dilakukan akan merangsang/mendorong pelanggan untuk membeli, memperoleh pelanggan baru, mempertahankan kontak hubungan dengan pelanggan, memperkenalkan produk baru, menjual lebih banyak kepada pelanggan lama dan 'mendidik' pelanggan. Dengan promosi penjualan yang dilakukan melalui pemberian diskon dengan sejumlah biaya yang dapat di atur untuk merangsang pembelian produk dengan segera untuk meningkatkan jumlah barang yang dibeli pelanggan. Hasil penelitian ini mendukung teorinya Alma (2005 yang mengungkapkan tujuan penggunaan promosi penjualan atau sales promotion antara lain; menarik para pembeli baru, memberi hadiah kepada langganan lama, menyuruh pembeli agar mengulangi pembeliannya, mencegah konsumen lari ke merek lain, meningkatkan loyalitas konsumen, meningkatkan volume penjualan dalam jangka pendek. Temuan ini juga sejalan dengan penelitian yang dilakukan oleh Boedilaksono (2007) yang menyatakan bahwa promosi penjualan berpengaruh positif terhadap volume penjualan.

Hasil penelitian menunjukkan bahwa biaya periklanan melalui media display, biaya promosi penjualan melalui pemberian diskon, dan biaya penjualan perorangan secara simultan memiliki pengaruh yang signifikan terhadap volume penjualan pada PT. Bintang Bali Indah Singaraja Tahun 2016 khusunya pada produk Bendera. Hasil penelitian ini sejalan dengan teorinya Kotler 
(2000:55) yang menyatakan ada beberapa faktor yang mempengaruhi volume penjualan diantaranya harga jual, produk, biaya promosi (periklanan, promosi penjualan, hubungan masyarakat, penjualan personal, penjualan langsung), saluran distribusi dan mutu. Hasil penelitian ini juga sesuai dengan temuan penelitian dari Putra (2017) yang menyimpulkan bahwa secara simultan variabel periklanan, promosi penjualan dan penjualan personal berpengaruh positif dan signifikan terhadap volume penjualan. Dalam penelitian ini terlihat sangat jelas bahwa biaya bauran promosi yaitu biaya periklanan melalui media display, biaya promosi penjualan melalui pemberian diskon dan biaya penjualan perorangan berperan secara bersama-sama dalam upaya meningkatkan volume penjualan pada PT. Bintang Bali Indah Singaraja Tahun 2016.

\section{SIMPULAN DAN SARAN Simpulan}

Berdasarkan hasil penelitian dan pembahasan, maka dapat disimpulkan sebagai berikut. Biaya Display tidak memiliki pengaruh signifikan terhadap volume penjualan pada PT. Bintang Bali Indah Singaraja Tahun 2016. Hal tersebut ditunjukkan dari hasil analisis ttes yang menunjukkan bahwa nilai $t_{\text {hitung }}=-0.742<$ $t_{\text {tabel }}=1,833$ atau $p$-value $=0.480>\alpha=$ 0.05 . Biaya Diskon berpengaruh signifikan terhadap volume penjualan pada PT. Bintang Bali Indah Singarja Tahun 2016. Hal tersebut ditunjukkan dari hasil ttes yang menunjukkan bahwa nilai $t_{\text {hitung }}=$ $2.422>t_{\text {tabel }}=1,833$ atau $p$-value $=0.042$ $<\alpha=0.05$. Biaya Penjualan Perorangan tidak memiliki pengaruh signifikan terhadap volume penjualan pada PT Bintang Bali Indah Singarja Tahun 2016. Hal tersebut ditunjukkan dari hasil analisis ttes yang menunjukkan bahwa nilai $t_{\text {hitung }}=1.718<t_{\text {tabel }}=1.833$ atau $p$-value $=$ $0.124>\alpha=0.05$. Biaya display, biaya diskon dan biaya penjualan perorangan berpengaruh signifikan terhadap volume penjualan pada PT. Bintang Bali Indah Singaraja Tahun 2016. Besarnya pengaruh biaya display, biaya diskon dan biaya penjualan perorangan terhadap volume penjualan secara simultan sebesar 0,524. Hal ini berarti volume penjualan pada PT. Bintang Bali Indah Singaraja Tahun 2016 sebesar $52,4 \%$ ditentukan oleh variabel biaya display, biaya diskon dan biaya penjualan perorangan, sedangkan sisanya sebesar $47,6 \%$ dipengaruhi oleh faktor lain yang tidak termasuk dalam penelitian ini.

\section{Saran}

Berdasarkan simpulan di atas, maka dapat dikemukakan saran sebagai berikut, yaitu: Bagi PT. Bintang Bali Indah Singaraja yang anggaran biaya bauran promosi yaitu periklanan yang dilakukan melalui media display dan biaya promosi melalui penjualan perorangan hendaknya ditingkatkan. Karena semakin besar anggaran biaya promosi yang tersedia maka akan memudahkan perusahaan untuk memilih media promosi yang lainnya. Kegiatan periklanan tidak hanya bisa dilakukan melalui display tetapi dengan menambah media periklanan yang lain seperti media luar ruang yaitu melalui billboard dan poster agar dapat meningkatkan penjualan perusahaan. Kegiatan penjualan perorangan juga bisa lebih efektif dengan menambah jumlah karyawan. Perusahaan agar tetap memperhatikan anggaran biaya promosi penjualan yang sudah dilakukan melalui pemberian diskon, karena pemberian diskon memiliki pengaruh yang besar untuk meningkatkan penjualan perusahaan. Diskon merupakan salah satu cara yang digunakan perusahaan untuk menarik minat pembeli untuk melakukan transaksi pembelian.

Bagi peneliti lain yang bermaksud melakukan penelitian mengenai pengaruh bauran promosi terhadap volume penjualan diharapkan untuk mengembangkan penelitian ini dengan menambah variabel bebasnya yang di duga dapat mempengaruhi volume penjualan seperti hubungan masyarakat (Publict Relation) dan penjualan langsung (direct marketing).

\section{DAFTAR PUSTAKA}

Alma, Buchari. 2013. Manajemen Pemasaran dan Pemasaran Jasa. Bandung: 
- 2005. Manajemen Pemasaran dan Pemasaran Jasa. Cetakan 5. Bandung: CV Alfabeta.

Boedileksono, Karlina. 2007. PengaruhBauran Promosi Terhadap Volume(Studi Kasus pada PT. IntanTunggal Kharisma, Yogyakarta). Skripsi (tidak diterbitkan). Fakultas Ekonomi Universitas SanataDharma Yogyakarta.

Dharmmesta, B.S. \& Irawan. 2010. Manajemen dan Pemasaran Modern. Cetakan Kedua Belas. Yogyakarta : Penerbit Liberty.

Daryono. 2011. Manajemen Pemasaran. Bandung: CV. Yrama Widya.

Dajan, Anto. 2000. Pengantar Metode Statistik. Jakarta : Pustaka LP3ES.

Handayani, Rosiana Tri. 2012. Bauran Pemasaran .Edisi 12 jilid 2. Jakarta:Erlangga

Kotler, Philip. 2000. Principles of Marketing, London: Prentice/Hall International,Inc.

Kotler \& Amstrong. 2012. Manajemen Pemasaran. Jilid 2. Jakarta: Bumi Aksara.

2008. Prinsip-prinsip Pemasaran. Jilid 1 dan 2.Edisi 12. Jakarta: Erlangga.

Kismono, Gugup. 2001. Bisnis Pengantar. Yogyakarta: BPF

Lupiyoadi, Rambat. 2013. Manajemen Pemasaran Jasa. Jakarta: Selemba Empat.

Oentoro, Deliyanti. 2012. Manajemen Pemasaran Modern. Yogyakarta : Laksbang PRESSindo.

Putra, I Made Juliada. 2017. Pengaruh Biaya Promosi Terhadap Volume Penjualan Pada CV.Yamaha Waja Motor Hayam Wuruk Denpasar. Skripsi (tidak diterbitkan). Fakultas Ekonomi Universitas Mahasaraswati Denpasar.

Swastha, Basu. 2004. Pengantar Bisnis Modern. Jakarta: Selemba Empat.
2002. Manajemen Pemasaran. Edisi Kedua. Cetakan Kedelapan. Jakarta: Penerbit Liberty

Simamora, Henry. 2010. Manajemen Pemasaran Internasional. Jilid II, Cetakan Pertama. Jakarta: Salemba Empat.

Tjiptono, F. 2008. Strategi Pemasaran. Edisi Ketiga. Yogyakarta : Penerbit CV Andi Offset. 